\title{
PENGEMBANGAN PERANGKAT PEMBELAJARAN IPA BERBASIS KETERAMPILAN PROSES UNTUK MENINGKATKAN KETERAMPILAN BERPIKIR KRITIS SISWA SD
}

\author{
Mochamad Yusuf $^{1}$, Budi Jatmiko², Suryanti ${ }^{3}$ \\ ${ }^{1}$ Mahasiswa Program Pascasarjana, Prodi Pendidikan Dasar, Universitas Negeri Surabaya, \\ ${ }^{2 \& 3}$ Dosen Pascasarjana, Prodi Pendidikan Dasar, Universitas Negeri Surabaya \\ e-mail: yusufsox@gmail.com
}

Received : November 2018

Reviewed : Desember 2018

Accepted : Januari 2019

Published : Januari 2019

\section{ABSTRACT}

The purpose of this research is to develop a learning package for Sciences Subject that can improve the critical thinking skill of the Elementary School Students. Therefore, in general, it can be categorized into a research and development. It can be done because of learning material with process skill to practice it not available. The learning package was developed by using 4-D model; defining, designing, developing, distributing. The subject in this study was learning material that will be tested in student of SD Raden Patah Surabaya. The result showed that learning material was valid, enforceability get good category with $100 \%$. Student activites by using process get good too. The improvement of students' critical thinking is consistent on 3 classes (IVA, IVB, and IVC), the significant and high improvement with the average of $N$-Gain of 0,75. The data of students' responses showed that most of students $(98,09 \%)$ are happy to the process skill based learning. Based on the results and findings of the research, it can be concluded that the developed learning package can be stated as a valid, practical, and effective learning package. The implication of the research is that the process skill based Sciences learning can improve students' critical thinking skill.

Keywords: Process Skill, Critical Thinking Skill.

\section{ABSTRAK}

Penelitian ini secara umum bertujuan untuk mengembangkan perangkat pembelajaran IPA yang dapat meningkatkan keterampilan berpikir kritis siswa SD. Oleh karena itu, secara umum jenis penelitian ini dapat dikategorikan sebagai penelitian pengembangan. Hal ini dilakukan karena perangkat pembelajaran berbasis keterampilan proses untuk meningkatkan keterampilan berpikir kritis belum tersedia. Perangkat pembelajaran yang dikembangkan menggunakan model 4-D yaitu pendefinisian, perancangan, pengembangan, dan penyebaran. Subyek dalam penelitian ini adalah perangkat pembelajaran yang diuji cobakan pada siswa SD Raden Patah Surabaya. Hasil penelitian menunjukkan bahwa perangkat valid, keterlaksanaan pembelajaran terlaksana dengan baik sebesar 100\%. Aktivitas siswa terlaksana dengan baik. Peningkatan keterampilan berpikir kritis siswa secara konsisten di tiga kelas (kelas IVA, IVB, dan IVC) mengalami peningkatan yang signifikan dan tergolong dalam kategori peningkatan tinggi dengan $N$-Gain ratarata sebesar 0,75. Data respon siswa menunjukkan mayoritas siswa (98,09\%) senang terhadap pembelajaran berbasis keterampilan proses. Berdasarkan hasil penelitian dan temuan-temuan sebagai dasar utama dapat disimpulkan bahwa perangkat pembelajaran yang dikembangkan dapat dinyatakan sebagai perangkat pemebalajaran yang valid, praktis, dan efektif. Implikasi penelitian yang dapat ditarik adalah pembelajaran IPA berbasis keterampilan proses dapat meningkatkan keterampilan berpikir kritis siswa. Berdasarkan hasil penelitian dan temuan-temuan sebagai dasar utama dapat disimpulkan bahwa perangkat pembelajaran yang dikembangkan dapat dinyatakan sebagai perangkat pemebalajaran yang valid, praktis, dan efektif. Implikasi penelitian yang dapat ditarik adalah pembelajaran IPA berbasis keterampilan proses dapat meningkatkan keterampilan berpikir kritis 
siswa.

Kata Kunci: Keterampilan Proses, Keterampilan Berpikir Kritis.

\section{PENDAHULUAN}

Ilmu Pengetahuan Alam (IPA) memiliki karakteristik tersendiri. Mulyasa, (2010:110) menyatakan Ilmu Pengetahuan Alam (IPA) merupakan mata pelajaran yang banyak mencari tahu tentang alam secara sistematis, sehingga pelajaran ini bukan hanya penguasaan kumpulan pengetahuanyang berupa fakta-fakta, konsep-konsep, atau prinsip-prinsip saja tetapi juga merupakan suatu proses penemuan, yang diharapkan dapat menjadi wahana bagi siswa Sekolah Dasar (SD) untuk mempelajari diri sendiri dan alam sekitarnya. Sehingga, dalam pembelajaran IPA diperlukan keterampilan-keterampilan proses sains yang menunjang pelaksanaan kegiatan pembelajaran.

Melalui pembelajaran berbasis keterampilan proses yang dirancang dalam pembelajaran maka diharapkan dapat meningkatkan keterampilan-keterampilan yang dibutuhkan pada abad 21. Salah satu keterampilan yang dibutuhkan adalah keterampilan berpikir kritis. Menurut Deanna dan Kuhn (2003:3), berpikir kritis merupakan kesadaran pemikiran sendiri dan refleksi pemikiran diri dan orang lain sebagai objek kognisi. Hal tersebut sesuai dengan teori belajar konstruktivisme. Melalui pengalaman belajar, maka siswa akan mengonstruksi sendiri pengetahuannya. Teori konstrukstivisme tersebut sejalan dengan keterampilan proses. Teori belajar lain yang mendukung adalah teori belajar konstruktivisme Vygotsky. Interaksi sosial dapat memudahkan belajar dan siswa membutuhkan bantuan belajar pada awal pembelajaran (Suyono, 2014:105).. Pengetahuan yang siswa bangun tidak dapat berjalan dengan baik tanpa ada bantuan dari orang lain. Selain itu teori belajar Bandura juga turut andil. Belajar akan lebih mudah jika dilakukan melalui pengalaman dan pemodelan.

Pada kenyataannya, berdasarkan wawancara dengan beberapa guru di Surabaya, perangkat pembelajaran yang dibuat oleh guru hanya untuk syarat administratif, bukan digunakan sebagai panduan untuk melakukan proses pembelajaran. Perangkat pembelajaran dibuat tanpa memperhatikan kebutuhan siswa, kesinambungan antara kompetensi dasar, indikator pembelajaran, tujuan pembelajaran, serta metode pembelajaran yang digunakan. Dengan perangkat pembelajaran tersebut, perencanaan pembelajaran menjadi kurang matang dan mengakibatkan tidak tercapainya tujuan pendidikan yang telah ditentukan. Selain itu penggunaan metode yang tidak cocok harus dipaksakan guru dalam melaksanakan kegiatan pembelajaran. Guru mendominasi dengan menggunakan metode ceramah dan menjadi satu-satunya sumber informasi yang membuat keterampilan berpikir kritis siswa rendah. OECD/Asian Development Bank (2015:29), menyatakan bahwa $75 \%$ pendidikan di Indonesia belum mengembangkan keterampilan berpikir kritis, baik pengembangan melalui sarana dan prasarana pembelajaran, tetapi juga perangkat pembelajaran yang digunakan. Berdasarkan The Making of Indonesian Education: An overview on Empowering Indonesian Teachers yang ditulis oleh Zulfikar (2009:14), diketahui bahwa meskipun guru memiliki peranan penting di kelas, namun masih banyak ditemukan kekurangan kompetensi guru.

Melalui keterampilan proses diduga dapat meningkatkan keterampilan berpikir kritis siswa. Menurut Suryanti, dkk dalam Modul Suplemen Pengembangan IPA SD (2011) mengungkapkan bahwa keterampilan proses adalah keterampilan-keterampilan mendasar yang menyangkut proses ilmiah atau cara kerja untuk memperoleh hasil atau produk. Menurut Samatowa (2011:93), keterampilan proses adalah keterampilan intelektual intelektual yang dimiliki dan digunakan dalam meneliti fenomena alam. Keterampilan proses sains tersebut dapat dipelajari oleh siswa dalam bentuk yang sederhana sesuai dengan tahap perkembangan anak usia sekolah dasar. Martin, dkk. dalam Rauf, dkk. (2013:47) membagi keterampilan proses menjadi dua kelompok yaitu keterampilan proses dasar dan keterampilan proses terpadu.

Berdasarkan uraian di atas, peneliti berupaya mengembangkan perangkat pembelajaran IPA berbasis keterampilan proses untuk meningkatkan keterampilan berpikir kritis yang layak digunakan.

\section{METODE PENELITIAN}

Pendekatan dalam penelitian ini adalah pendekatan kuantitatif. Penelitian ini secara umum bertujuan untuk mengembangkan perangkat pembelajaran IPA yang dapat meningkatkan keterampilan berpikir kritis siswa kelas IV SD. Oleh karena itu, secara umum jenis penelitian ini dapat dikategorikan sebagai penelitian pengembangan. Perangkat pembelajaran yang dikembangkan dalam penelitian ini meliputi silabus, rencana pelaksanaan pembelajaran (RPP), buku siswa, lembar kegiatan siswa, dan lembar penilaian.

Pengembangan perangkat dilakukan dengan menggunakan rancangan ujicoba pretes and postes grup dengan replikasi untuk mengetahui konsistensi peningkatan 
keterampilan berpikir kritis menggunakan perangkat pembelajaran IPA berbasis keterampilan proses. Pengembangan perangkat dilakukan untuk melihat kesesuaian pembelajaran dan karakteristik siswa sehingga dapat dijadikan masukan. Pada ujicoba terbatas dan ujicoba lapangan, sebelum melaksanakan pembelajaran berbasis keterampilan proses dilaksanakan tes awal dan setelah melaksanakan pembelajaran dilaksanakan tes akhir. Pengembangan perangkat pembelajaran mengikuti 4-D model design yang menyatakan bahwa proses pengembangan perangkat model 4-D terdiri atas define, design, develop, dan desseminate (Thiagarajan, 1974). Model 4-D tersebut direduksi menjadi 3-D karena setelah tahap pengembangan sudah diperoleh perangkat yang memenuhi kriteria yang ditetapkan.

Subjek dalam penelitian ini adalah perangkat pembelajaran IPA berbasis keterampilan proses yang diujicobakan pada siswa kelas IV SDI Raden Patah Surabaya. Ujicoba terbatas dilaksanakan di kelas IV SDI Raden Patah Surabaya dalam satu kelas yang berjumlah 10 siswa yang dipilih secara acak. Sedangkan ujicoba lapangan dilakukan di tiga kelas IV SDI Raden Patah Surabaya dengan replikasi yang rinciannya adalah kelas IVA merupakan kelas implementasi yang berjumlah 32 siswa, kelas IVB merupakan kelas replikasi I yang berjumlah 30 siswa, dan kelas IVC merupakan kelas replikasi II yang berjumlah 32 siswa. Yang bertindak sebagai guru pada ujicoba terbatas adalah peneliti dan pada ujicoba lapangan adalah guru kelas.

Teknik pengumpulan data dalam penelitian ini dilakukan dengan: (a) observasi; (b) tes; (c) catatan lapangan. Instrumen yang dikembangkan untuk mengumpulkan data dalam penelitian meliputi: (a) lembar validasi perangkat dan instrumen validasi, (b) lembar penilaian keterbacaan BAS, (c) lembar angket tingkat kesulitan BAS, (d) lembar keterlaksanaan pembelajaran, (e) lembar pengamatan aktivitas siswa, (f) lembar kendala pelaksanaan pembelajaran, (g) tes keterampilan berpikir kritis, dan (h) angket respon siswa.

Dalam penilaian keterampilan berpikir kritis digunakan tes uraian berjumlah 10 soal yang disusun bedasarkan indikator Facione. Facione (1990:6) mengemukakan bahwa keterampilan berpikir kritis meliputi: (1) interpretasi, (2) analisis, (3) evaluasi, (4) inferensi, (5) eksplanasi, dan (6) pengaturan diri. Namun pada fase pengaturan diri tidak disertakan karena tingkat berpikir siswa kelas IV yang masih belum tinggi.

Analisis validitas perangkat pembelajaran meliputi Silabus, RPP, BAS, LKS, dan Lembar Penilaian Keterampilan Berpikir Kritis. Data yang diperoleh dianalisis dengan mempertimbangkan saran-saran dari validator. Hasil analisis tersebut dijadikan sebagai pedoman untuk merevisi perangkat pembelajaran. Untuk masing-masing validator memiliki skala penilaian atau kriteria kelayakan tersendiri. Validitas perangkat ditentukan dengan merata-rata skor dari masing-masing komponen yang dapat dideskripsikan berdasarkan adaptasi dari Ratumanan (2006) sebagai berikut:

$1,00 \leqslant \mathrm{SV} \geqslant 1,50$ : sangat tidak valid

$1,51 \leqslant \mathrm{SV} \geqslant 2,50:$ tidak valid

$2,51 \leqslant \mathrm{SV} \geqslant 3,50:$ valid

$3,51 \leqslant \mathrm{SV} \geqslant 4,00:$ sangat valid

Keterangan: $\mathrm{SV}=$ Skor Validasi

Draft hasil rancangan awal yang divalidasi oleh para pakar dikatakan valid jika rata-rata skor yang diberikan berkategori minimal cukup baik.

Tingkat reliabilitas instrumen dihitung dengan rumus:

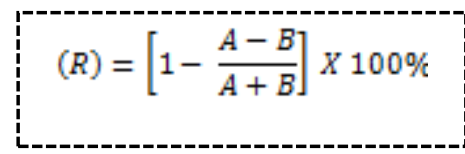

\section{Keterangan:}

$\mathrm{R}=$ Realibiltas (instrumen dianggap reliabel bila $\mathrm{R} \geqslant 75 \%$ ) $\mathrm{A}=$ Frekuensi aspek tingkah laku yang teramati oleh pengamat memberikan frekuensi tinggi.

$\mathrm{B}=$ Frekuensi aspek tingkah laku yang teramati oleh pengamat memberikan frekuensi tinggi.

(Borrich, dalam Trianto, 2009:240)

Tingkat keterbacaan dihitung dengan membandingkan banyak kata yang diisi benar dengan jumlah keseluruhan kata yang harus diisi, hasilnya kemudian dikalikan $100 \%$.

Perhitungan keterbacaan menggunakan rumus.

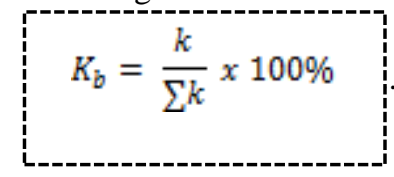

Keterangan:

(diadaptasi dari Arifin, 2009)

$\mathrm{K}_{\mathrm{b}} \quad=$ tingkat keterbacaan

$\mathrm{k} \quad=$ frekuensi kata yang bisa dapat diisi

$\sum \mathrm{k} \quad=$ jumlah seluruh kata yang harus diisi

Hasil perhitungan kemudian diinterpretasikan menggunakan kriteria keterbacaan yang diadopsi dari Sitepu (2010) yaitu lebih dari 75\% maka kategori teks adalah mudah, apabila hasil diantara 20\% - 75\% maka kategori teks adalah sedang, dan apabila hasil kurang dari $20 \%$ maka kategori teks adalah sulit. 
Tingkat kesulitan dihitung dengan mengetahui skor jumlah kata, kalimat, dan gambar yang sukar dipahami dibagi keseluruhan kata, kalimat, dan gambar yang kemudian hasil dikalikan 100\% (Prasetyo, 40:2011). Hasil penskoran dideskripsikan sebagai berikut:

$0,00 \%-20,0 \%$ : sangat rendah/sangat mudah dipahami

$21,0 \%-40,9 \%:$ rendah/mudah dipahami

$41,0 \%-59,9 \%$ : sedang/kurang mudah dipahami

$60,0 \%-79,9 \%:$ sulit/sulit dipahami

$80,0 \%-100 \%$ : sangat sulit/sangat sulit dipahami

(Diadaptasi dari Ratumanan dan Laurens, 2003)

Analisis keterlaksanaan kegiatan pembelajaran dilakukan oleh dua pengamat yang sudah dilatih sehingga memahami lembar pengamatan secara benar. Analisis penilaian keterlaksanaan pembelajaran diamati dengan menggunakan skor 0-4 sesuai dengan rubrik penilaian keterlaksanaan pembelajaran. Sedangkan analisis persentase keterlaksanaan pembelajaran dapat dihitung dengan menggunakan persamaan.

$$
P=\frac{\Sigma K}{\Sigma N} \times 100 \%
$$

(diadaptasi dari Arifin, 2009)

\section{Keterangan:}

$\mathrm{P}=$ persentase keterlaksanaan

$\sum \mathrm{K}=$ jumlah aspek yang terlaksana

$\sum \mathrm{N}=$ jumlah seluruh aspek yang dialami

Persentase keterlaksanaan menggunakan skala:

$\mathrm{P}=0 \%-24 \% \quad:$ tidak terlaksana

$\mathrm{P}=25 \%-49 \% \quad:$ terlaksana kurang

$\mathrm{P}=50 \%-74 \% \quad$ : terlaksana cukup baik

$\mathrm{P}=75 \%-100 \%$ : terlaksana baik

(Sugiyono, 2012:93)

Data pengamatan aktivitas siswa dilakukan untuk memberikan deskripsi aktivitas siswa selama kegiatan pembelajaran berbasis keterampilan proses. Analisis data pengamatan aktivitas siswa dilakukan oleh dua pengamat yang sudah dilatih sehingga memahami lembar pengamatan secara benar. Data hasil pengamatan aktivitas siswa selama kegiatan pembelajaran menggunakan persentase. Aktivitas siswa dapat dihitung dengan rumus:

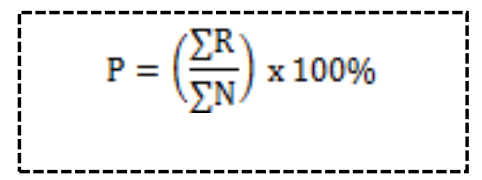

(Diadaptasi dari Arifin, 2009)

Keterangan:

$\mathrm{P}=$ persentase aktivitas siswa $\sum \mathrm{R}=$ jumlah frekuensi kategori pengamatan

$\sum \mathrm{N}=$ jumlah frekuensi seluruh kategori pengamatan

Kendala pelaksanan pembelajaran dianalisis dengan pengamat dan peneliti memberikan catatan kendala yang terjadi pada pelaksanaan pembelajaran.

Signifikansi peningkatan keterampilan berpikir kritis diperoleh dari uji hipotesis dengan menggunakan Uji $\mathrm{T}$ (T-Test) dengan syarat bahwa data yang akan dianalisis berdistribusi normal. Rumus yang digunakan adalah

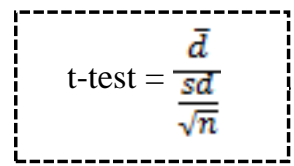

$\bar{d}=$ nilai rata-rata perbedaan antara pengamatan berpasangan

sd $=$ standar deviasi perbedaan antara pengamatan berpasangan

$\mathrm{n}=$ jumlah sampel

Untuk mengetahui derajat peningkatan keterampilan berpikir kritis dilakukan analisis statistik inferensial melalui analisis $\mathrm{N}$-gain score (nilai pretes dan posttes keterampilan berpikir kritis) dengan rumus.

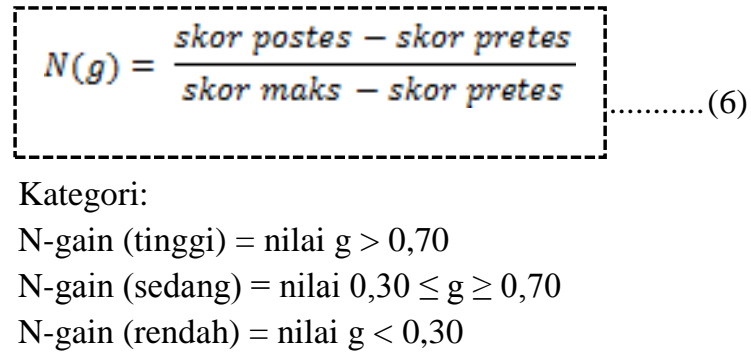

Kategori:

$\mathrm{N}$-gain $($ tinggi $)=$ nilai $\mathrm{g}>0,70$

$\mathrm{N}$-gain $($ rendah $)=$ nilai $\mathrm{g}<0,30$

(Sundayana, 2015:151)

Untuk melihat konsistensi pengaruh pembelajaran terhadap peningkatan keterampilan berpikir kritis siswa menggunakan analisis varian atau ANOVA. Hal ini dilakukan dengan menggunakan analisis varians satu jalur (One-Way Anova). Pengujian ANOVA ini terdapat prasyarat yaitu uji normalitas dan homogenitas. Langkahlangkah pengujian ANOVA antara lain:

Adapun untuk perhitungan ANOVA, penulis menggunakan bantuan aplikasi IBM SPSS 23. Pengambilan keputusan pada perhitungan menggunakan aplikasi IBM SPSS 23 adalah dengan melihat nilai sig. Apabila nilai sig.>0,05 (taraf signifikansi 5\%) maka dapat disimpulkan tidak terdapat perbedaan antara peningkatan keterampilan berpikir kritis di kelas IVA, IVB, dan IVC.

Data respon siswa dilakukan untuk memberikan deskripsi respon siswa selama kegiatan pembelajaran berbasis keterampilan proses. Data hasil pengamatan respon siswa selama kegiatan pembelajaran menggunakan 
persentase. Hasil analisis respon siswa diinterpretasikan menggunakan skala Likert. Data respon yang diperoleh digunakan untuk menindak lanjuti pembelajaran berbasis keterampilan proses. Respon siswa dapat dihitung dengan rumus:

$$
\mathrm{P}=\left(\frac{\Sigma \mathrm{K}}{\Sigma \mathrm{N}}\right) \times 100 \%
$$

(Diadaptasi dari Arifin, 2009)

Keterangan:

$\mathrm{P}=$ persentase respon siswa

$\sum \mathrm{R}=$ jumlah skor respon siswa

$\sum \mathrm{N}=$ jumlah seluruh skor respon siswa

Hasil persentase pengamatan aktvitas siswa dideskripsikan menggunakan skala Likert (Sugiyono, 2012:93) sebagai berikut:

$0 \%-49 \%=$ tidak baik

$50 \%-64 \%=$ kurang baik

$65 \%-84 \%=$ cukup baik

$85 \%-100 \%=$ baik

\section{HASIL DAN PEMBAHASAN}

\section{Hasil Penelitian}

Secara keseluruhan validitas perangkat pembelajaran yang dinilai oleh dua validator dapat dilihat pada Tabel 1 .

Tabel 1.

Rekapitulasi Hasil Validasi Perangkat Pembelajaran

\begin{tabular}{llcc}
\hline No. & $\begin{array}{c}\text { Aspek } \\
\text { Penilaian }\end{array}$ & Rata-Rata & $\begin{array}{c}\text { Persentase } \\
\text { Kecocokan }\end{array}$ \\
1 & Silabus & 3,62 & 0,96 \\
2 & RPP & 3,64 & 0,96 \\
3 & LKS & 3,72 & 0,98 \\
4 & BAS & 3,63 & 0,97 \\
5 & LP & 3,59 & 0,96 \\
\hline
\end{tabular}

Hasil dari kedua validator pada Tabel 1 . menunjukkan bahwa perangkat pembelajaran secara keseluruhan telah memenuhi unsur kevalidan dan instrumen yang disusun reliabel. Sehingga perangkat pembelajaran dinyatakan layak untuk diujicobakan.

Berdasarkan hasil uji keterbacaan BAS pada 10 siswa kelas IV, maka rata-rata persentase tingkat keterbacaan siswa adalah sebesar 87,50\%. Hal itu menunjukkan bahwa buku siswa memiliki tingkat keterbacaan tinggi/mudah. (Sitepu, 2010)

Tingkat kesulitan buku ajar siswa dilakukan pada 10 siswa kelas IV adalah tingkat kesulitan kata dalam BAS mendapatkan persentase rata-rata $1,03 \%$ yang artinya kata dalam BAS sangat mudah dipahami siswa. Kalimat yang sulit mendapatkan persentase rata-rata $2,18 \%$ yang artinya kalimat sangat mudah dimengerti siswa. Gambar yang sulit dimengerti siswa mendapatkan persentase rata-rata $10,83 \%$ yang artinya gambar sangat mudah dimengerti siswa.

Hasil kepraktisan perangkat pembelajaran disusun berdasarkan data yang diperoleh dari kegiatan ujicoba lapangan yang dilaksanakan terhadap siswa kelas IV. Kepraktisan perangkat pembelajaran dapat dilihat dari keterlaksanaan pembelajaran dan kendala-kendala saat pelaksanaan pembelajaran.

Berdasarkan kegiatan pembelajaran pada kelas A, penilaian pembelajaran yang dilakukan oleh dua pengamat pada pertemuan 1 mendapatkan rata-rata nilai 3,80 dan tingkat reliabilitas 99,22\%. Hal tersebut menunjukkan bahwa RPP pertemuan 1 terlaksana dengan baik dan instrumen yang digunakan reliabel. Pada pertemuan 2 mendapatkan rata-rata nilai 3,84 dan tingkat reliabilitas 98,29\%. Hal tersebut menunjukkan bahwa RPP pertemuan 2 terlaksana dengan baik dan instrumen yang digunakan reliabel. Pada pertemuan 3 mendapatkan rata-rata nilai 3,98 dan tingkat reliabilitas $99,80 \%$. Hal tersebut menunjukkan bahwa RPP pertemuan 3 terlaksana dengan baik dan instrumen yang digunakan reliabel.

Berdasarkan kegiatan pembelajaran di kelas B, penilaian pembelajaran yang dilakukan oleh dua pengamat pada pertemuan 1 mendapatkan rata-rata nilai 3,89 dan tingkat reliabilitas 99,03\%. Hal tersebut menunjukkan bahwa RPP pertemuan 1 terlaksana dengan baik dan instrumen yang digunakan reliabel. Pada pertemuan 2 mendapatkan rata-rata nilai 3,88 dan tingkat reliabilitas 99,44\%. Hal tersebut menunjukkan bahwa RPP pertemuan 2 terlaksana dengan baik dan instrumen yang digunakan reliabel. Pada pertemuan 3 mendapatkan rata-rata nilai 3,96 dan tingkat reliabilitas $99,80 \%$. Hal tersebut menunjukkan bahwa RPP pertemuan 3 terlaksana dengan baik dan instrumen yang digunakan reliabel.

Berdasarkan kegiatan pembelajaran di kelas C, penilaian pembelajaran yang dilakukan oleh dua pengamat pada pertemuan 1 mendapatkan rata-rata nilai 3,87 dan tingkat reliabilitas 99,03\%. Hal tersebut menunjukkan bahwa RPP pertemuan 1 terlaksana dengan baik dan instrumen yang digunakan reliabel. Pada pertemuan 2 mendapatkan rata-rata nilai 3,88 dan tingkat reliabilitas 99,44\%. Hal tersebut menunjukkan bahwa RPP pertemuan 2 terlaksana dengan baik dan instrumen yang digunakan reliabel. Pada pertemuan 3 mendapatkan rata-rata nilai 3,89 dan tingkat reliabilitas $98,32 \%$. Hal tersebut menunjukkan bahwa RPP pertemuan 3 terlaksana dengan baik dan instrumen yang digunakan reliabel. 
Aktivitas siswa di kelas A menunjukkan bahwa siswa lebih sering melakukan aktivitas memperhatikan guru. Hal tersebut dikarenakan siswa lebih sering memperhatikan penjelasan guru berupa instruksi pada saat melakukan percobaan. Sedangkan yang jarang dilakukan adalah kegiatan untuk mempresentasikan hasil percobaan. Hal tersebut dikarenakan presentasi hasil percobaan dilakukan setelah percobaan dan bergantian dengan kelompok lain.

Aktivitas siswa di kelas B menunjukkan bahwa siswa lebih sering melakukan aktivitas memperhatikan guru. Hal tersebut dikarenakan siswa lebih sering memperhatikan penjelasan guru berupa instruksi pada saat melakukan percobaan. Sedangkan yang jarang dilakukan adalah kegiatan untuk mempresentasikan hasil percobaan. Hal tersebut dikarenakan presentasi hasil percobaan dilakukan setelah percobaan dan bergantian dengan kelompok lain.

Aktivitas siswa di kelas $\mathrm{C}$ menunjukkan bahwa siswa lebih sering melakukan aktivitas memperhatikan guru. Hal tersebut dikarenakan siswa lebih sering memperhatikan penjelasan guru berupa instruksi pada saat melakukan percobaan. Sedangkan yang jarang dilakukan adalah kegiatan untuk mempresentasikan hasil percobaan. Hal tersebut dikarenakan presentasi hasil percobaan dilakukan setelah percobaan dan bergantian dengan kelompok lain.

Data hasil kendala-kendala saat pembelajaran diperoleh pada saat pembelajaran di kelas A, B, dan C. Kendala yang ditemukan di lapangan dalam pembelajaran yang dilakukan selama tiga pertemuan pada masing-masing kelas dapat dilihat pada Tabel 2.

Tabel 2.

Kendala-Kendala dan Solusi saat Pembelajaran

\begin{tabular}{|c|c|}
\hline & \\
\hline $\begin{array}{l}\text { Banyak siswa yang bermain- } \\
\text { main dengan alat-alat } \\
\text { pembelajaran. }\end{array}$ & $\begin{array}{l}\text { Guru harus lebih tegas } \\
\text { dalam memperingatkan } \\
\text { siswa agar siswa lebih } \\
\text { fokus dalam pembelajaran. }\end{array}$ \\
\hline $\begin{array}{l}\text { Siswa kurang terbiasa dalam } \\
\text { pembelajaran yang berbasis } \\
\text { keterampilan proses, sehingga } \\
\text { siswa masih kesulitan dalam } \\
\text { menentukan pertanyaan dan } \\
\text { membuat prediksi. }\end{array}$ & $\begin{array}{l}\text { Guru memberikan } \\
\text { konkrit dengan contoh } \\
\text { menjelaskan }\end{array}$ \\
\hline $\begin{array}{lr}\text { Siswa tidak } & \text { biasa } \\
\text { menggunakan alat } & \text { seperti } \\
\text { stopwatch, sehingga } & \text { bingung } \\
\text { dalam penggunaannya. }\end{array}$ & $\begin{array}{l}\text { Guru mendemonstrasikan } \\
\text { cara penggunaan stopwatch } \\
\text { sampai siswa benar-benar } \\
\text { mengerti. }\end{array}$ \\
\hline
\end{tabular}

Analisis hasil keterampilan berpikir kritis kelas ujicoba lapangan didasarkan pada data hasil tes keterampilan berpikir kritis siswa kelas IVA dan dianalisis menggunakan rumus Uji-t dan $N$-Gain. Uji-t digunakan untuk menghitung signifikansi peningkatan keterampilan berpikir kritis, sedangkan $N$-Gain untuk menghitung derajat peningkatan keterampilan berpikir kritis.

Dalam pengujian menggunakan rumus Uji-t berpasangan, syarat data yang harus terpenuhi adalah data berdistribusi normal. Uji normalitas menggunakan rumus Shapiro-Wilk dengan bantuan aplikasi IBM SPSS. Berdasarkan hasil uji normalitas menggunakan aplikasi IBM SPSS 23, hasil nilai sig. pada nilai pretes sebesar 0,191 dan nilai postes sebesar 0,102 . Karena hasil nilai sig. $>0,05$ maka data pretes dan postes berdistribusi normal. Apabila data yang diperoleh berdistribusi normal maka selanjutnya dapat dilakukan analisis dengan menggunakan Uji-t. Untuk melihat apakah terdapat signifikansi peningkatan keterampilan berpikir kritis, maka hasil pretes dan postes dianalisis menggunakan Uji-t dengan bantuan aplikasi IBM SPSS 23.

Hasil Uji-t diperoleh dari data pretes dan posttes pada 32 siswa kelas IVA menunjukkan bahwa nilai sig.(2tailed) sebesar 0,000. Karena nilai sig. sig.(2-tailed) $<0,05$, maka dapat disimpulkan terdapat perbedaan yang signifikan antara nilai pretes dan nilai posttes.

Untuk melihat derajat pengaruh keefektifan pembelajaran dapat dianalisis menggunakan rumus $N$ Gain. Derajat peningkatan tiap indikator soal berpikir kritis siswa dapat dilihat pada Tabel 3.

Tabel 3.

$N$-Gain tiap Indikator Keterampilan Berpikir Kritis Kelas IVA

\begin{tabular}{llll}
\hline No & Indikator keterampilan berpikir kritis & N-Gain \\
\hline 1 & $\begin{array}{l}\text { Membuat atau merumuskan dengan tepat } \\
\text { kategori, perbedaan, atau kelompok untuk }\end{array}$ & 0,74 \\
& $\begin{array}{l}\text { memahami, mendeskripsikan, atau } \\
\text { karakterisasi informasi. }\end{array}$ & \\
\hline 2 & $\begin{array}{l}\text { Menentukan penyataan, deskripsi, } \\
\text { pertanyaan, atau represi grafis data yang }\end{array}$ & \\
& bermaksud mengungkapkan alasan-alasan \\
& untuk mendukung atau menentang klaim, & \\
& pendapat, atau sudut pandang \\
\hline 3 & $\begin{array}{l}\text { Menentukan apakah suatu argumen } \\
\text { membenarkan penerimaan seseorang } \\
\text { sebagai penerimaan yang benar. }\end{array}$ & \\
\hline 4 & $\begin{array}{l}\text { Menghubungkan seperangkat pernyataan, } \\
\text { uraian, pertanyaan, atau bentuk }\end{array}$ & 0,72 \\
& $\begin{array}{l}\text { representasi lain, dengan tingkat kekuatan } \\
\text { logika yang tepat. }\end{array}$ \\
\hline 5 & $\begin{array}{l}\text { Memberi alasan untuk menerima beberapa } \\
\text { klaim. }\end{array}$ & 0,76 \\
\hline
\end{tabular}


Berdasarkan Tabel 3. menunjukkan bahwa meskipun nilai $\mathrm{N}$-Gain bervariasi, ternyata kategori peningkatan keterampilan berpikir kritis siswa pada tiap indikator sama. Pada indikator 1-5 menunjukkan kategori tinggi. Selain dianalisis berdasarkan data tiap indikator keterampilan berpikir kritis, data juga dianalisis berdasarkan nilai tiap siswa. Hasil analisis peningkatan keterampilan berpikir kritis tiap siswa dapat dilihat pada Gambar 1.

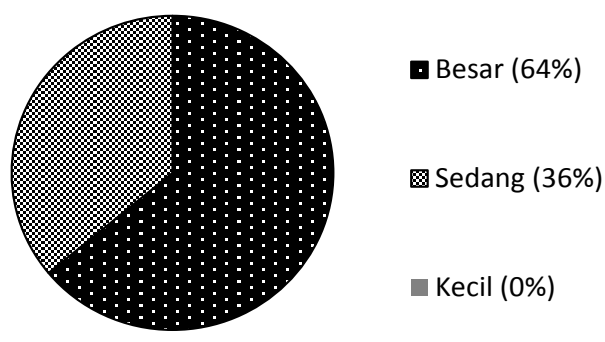

Gambar 1.

$\mathrm{N}$-Gain tiap Siswa Keterampilan Berpikir Kritis Kelas IVA

Berdasarkan Gambar 1., diketahui bahwa terdapat peningkatan keterampilan berpikir kritis siswa secara signifikan setelah dilakukan pembelajaran berbasis keterampilan proses. $N$-Gain setiap siswa kelas IVA menunjukkan bahwa 21 siswa (64\%) menunjukkan peningkatan kategori tinggi, sedangkan 11 siswa (36\%) menunjukkan peningkatan kategori sedang. Secara keseluruhan rata-rata $N$-Gain setiap siswa adalah 0,75 dengan kategori tinggi.

Analisis hasil keterampilan berpikir kritis kelas replikasi 1 didasarkan pada data hasil tes keterampilan berpikir kritis siswa di kelas IVB dan dianalisis menggunakan rumus Uji-t dan $\mathrm{N}$-Gain. Uji-t digunakan untuk menghitung signifikansi peningkatan keterampilan berpikir kritis, sedangkan $N$-Gain untuk menghitung derajat peningkatan keterampilan berpikir kritis.

Dalam pengujian menggunakan rumus Uji-t berpasangan, syarat data yang harus terpenuhi adalah data berdistribusi normal. Uji normalitas menggunakan rumus Shapiro-Wilk dengan bantuan aplikasi IBM SPSS. Berdasarkan hasil uji normalitas menggunakan bantuan aplikasi IBM SPSS 23 diperoleh hasil nilai sig. pada nilai pretes sebesar 0,166 dan nilai postes sebesar 0,161. Karena hasil nilai sig.>0,05 maka data pretes dan postes berdistribusi normal. Apabila data yang diperoleh berdistribusi normal maka selanjutnya dapat dilakukan analisis dengan menggunakan Uji-t. Untuk melihat apakah terdapat signifikansi peningkatan keterampilan berpikir kritis, maka hasil pretes dan postes dianalisis menggunakan Uji-t dengan bantuan aplikasi IBM SPSS 23.

Hasil Uji-t diperoleh dari data pretes dan posttes pada 30 siswa kelas IVB menunjukkan bahwa nilai sig.(2tailed) sebesar 0,000. Karena nilai sig. $(2$-tailed $)<0,05$, maka dapat disimpulkan terdapat perbedaan antara nilai pretes dan nilai posttes.

Untuk melihat derajat pengaruh keefektifan pembelajaran dapat dianalisis menggunakan rumus $\mathrm{N}$ Gain. Derajat peningkatan tiap indikator soal berpikir kritis siswa dapat dilihat Tabel 4.

Tabel 4.

$N$-Gain tiap Indikator Keterampilan Berpikir Kritis Kelas IVB

\begin{tabular}{lll}
\hline No & Indikator keterampilan berpikir kritis & $\begin{array}{l}\text { N- } \\
\text { Gain }\end{array}$ \\
\hline 1 & $\begin{array}{l}\text { Membuat atau merumuskan dengan tepat } \\
\text { kategori, perbedaan, atau kelompok untuk } \\
\text { memahami, mendeskripsikan, atau } \\
\text { karakterisasi informasi. }\end{array}$ & \\
& $\begin{array}{l}\text { Menentukan penyataan, deskripsi, } \\
\text { pertanyaan, atau represi grafis data yang }\end{array}$ & 0,76 \\
& bermaksud mengungkapkan alasan-alasan \\
& untuk mendukung atau menentang klaim, \\
pendapat, atau sudut pandang & \\
\hline 3 & $\begin{array}{l}\text { Menentukan apakah suatu argumen } \\
\text { membenarkan penerimaan seseorang sebagai } \\
\text { penerimaan yang benar. }\end{array}$ & 0,75 \\
\hline 4 & $\begin{array}{l}\text { Menghubungkan seperangkat pernyataan, } \\
\text { uraian, pertanyaan, atau bentuk representasi }\end{array}$ & 0,73 \\
& $\begin{array}{l}\text { lain, dengan tingkat kekuatan logika yang } \\
\text { tepat. }\end{array}$ \\
\hline 5 & $\begin{array}{l}\text { Memberi alasan untuk menerima beberapa } \\
\text { klaim. }\end{array}$ & 0,73 \\
\hline
\end{tabular}

Berdasarkan Tabel 4. menunjukkan bahwa meskipun nilai N-Gain bervariasi, ternyata kategori peningkatan keterampilan berpikir kritis siswa pada tiap indikator sama. Pada indikator 1-5 menunjukkan kategori tinggi.

Selain dianalisis berdasarkan data tiap indikator keterampilan berpikir kritis, data juga dianalisis berdasarkan nilai tiap siswa. Hasil rekapitulasi analisis peningkatan keterampilan berpikir kritis tiap siswa dapat dilihat pada Gambar 2. 


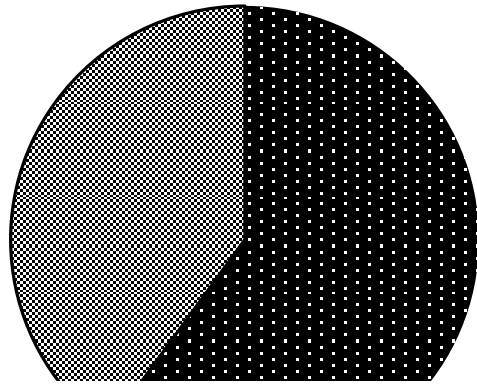

: Tir

Gambar 2.

$N$-Gain tiap Siswa Keterampilan Berpikir Kritis Kelas IVB

Berdasarkan Gambar 2, diketahui bahwa terdapat peningkatan keterampilan berpikir kritis siswa secara signifikan setelah dilakukan pembelajaran berbasis keterampilan proses. Sejumlah 18 siswa (60\%) menunjukkan peningkatan kategori tinggi, sedangkan 12 siswa (40\%) menunjukkan peningkatan kategori sedang. Secara keseluruhan rata-rata $N$-Gain setiap siswa adalah 0,75 dengan kategori tinggi.

Analisis hasil keterampilan berpikir kritis kelas replikasi 2 didasarkan pada data hasil tes keterampilan berpikir kritis siswa di kelas IVC dan dianalisis menggunakan rumus Uji-t dan $N$-Gain. Uji-t digunakan untuk menghitung signifikansi peningkatan keterampilan berpikir kritis, sedangkan $\mathrm{N}$-Gain untuk menghitung derajat peningkatan keterampilan berpikir kritis.

Dalam pengujian menggunakan rumus Uji-t berpasangan, syarat data yang harus terpenuhi adalah data berdistribusi normal. Uji normalitas menggunakan rumus Shapiro-Wilk dengan bantuan aplikasi IBM SPSS. Berdasarkan hasil uji normalitas menggunakan bantuan aplikasi IBM SPSS 23 diperoleh hasil nilai sig. pada nilai pretes sebesar 0,090 dan nilai postes sebesar 0,102. Karena hasil nilai sig. $>0,05$ maka data pretes dan postes berdistribusi normal. Apabila data yang diperoleh berdistribusi normal maka selanjutnya dapat dilakukan analisis dengan menggunakan Uji-t. Untuk melihat apakah terdapat signifikansi peningkatan keterampilan berpikir kritis, maka hasil pretes dan postes dianalisis menggunakan Uji-t dengan bantuan aplikasi IBM SPSS 23.

Hasil Uji-t diperoleh dari data pretes dan posttes pada 32 siswa kelas IVC menujunkkan bahwa nilai sig.(2tailed) sebesar 0,000. Karena nilai sig. $(2$-tailed $)<0,05$, maka dapat disimpulkan terdapat perbedaan antara nilai pretes dan nilai posttes.

Untuk melihat derajat pengaruh keefektifan pembelajaran dapat dianalisis menggunakan rumus $N$ -
Gain. Derajat peningkatan tiap indikator soal berpikir kritis siswa dapat dilihat Tabel 5.

Tabel 5.

$N$-Gain tiap Indikator Keterampilan Berpikir Kritis Kelas IVC

\begin{tabular}{llc}
\hline No & Indikator keterampilan berpikir kritis & N-Gain \\
\hline 1 & $\begin{array}{l}\text { Membuat atau merumuskan dengan tepat } \\
\text { kategori, perbedaan, atau kelompok untuk }\end{array}$ & 0,72 \\
& $\begin{array}{l}\text { memahami, mendeskripsikan, atau } \\
\text { karakterisasi informasi. }\end{array}$ & \\
\hline 2 & $\begin{array}{l}\text { Menentukan penyataan, deskripsi, } \\
\text { pertanyaan, atau represi grafis data yang }\end{array}$ & 0,72 \\
& $\begin{array}{l}\text { bermaksud mengungkapkan alasan-alasan } \\
\text { untuk mendukung atau menentang klaim, }\end{array}$ & \\
& pendapat, atau sudut pandang \\
\hline 3 & $\begin{array}{l}\text { Menentukan apakah suatu argumen } \\
\text { membenarkan penerimaan seseorang }\end{array}$ & 0,71 \\
& sebagai penerimaan yang benar. \\
\hline 4 & $\begin{array}{l}\text { Menghubungkan seperangkat pernyataan, } \\
\text { uraian, pertanyaan, atau bentuk } \\
\text { representasi lain, dengan tingkat kekuatan } \\
\text { logika yang tepat. }\end{array}$ \\
\hline 5 & $\begin{array}{l}\text { Memberi alasan untuk menerima beberapa } \\
\text { klaim. }\end{array}$ & 0,72 \\
\hline
\end{tabular}

Berdasarkan Tabel 5. menunjukkan bahwa meskipun nilai N-Gain bervariasi, ternyata kategori peningkatan keterampilan berpikir kritis siswa pada tiap indikator sama. Pada indikator 1-5 menunjukkan kategori tinggi.

Selain dianalisis berdasarkan data tiap indikator keterampilan berpikir kritis, data juga dianalisis berdasarkan nilai tiap siswa. Hasil analisis peningkatan keterampilan berpikir kritis tiap siswa dapat dilihat pada Gambar 3.

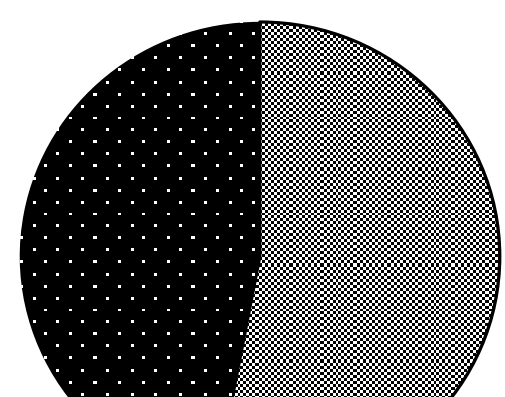

Gambar 3.

$N$-Gain tiap Siswa Keterampilan Berpikir Kritis Kelas C

Berdasarkan Gambar 3, diketahui bahwa terdapat peningkatan keterampilan berpikir kritis siswa secara signifikan setelah dilakukan pembelajaran berbasis keterampilan proses. Sejumlah 17 siswa (53\%) 
menunjukkan peningkatan kategori tinggi, sedangkan 15 siswa (47\%) menunjukkan peningkatan kategori sedang.

Konsistensi pengaruh perangkat pembelajaran IPA berbasis keterampilan proses terhadap keterampilan berpikir kritis siswa dapat dilihat dengan menggunakan analisis varians satu jalur (One-Way Anova). Hasil uji anova diperoleh dari data pretes dan postes pada kelas IVA (kelas Ujicoba Lapangan), IVB (Kelas Replikasi 1), dan IVC (Kelas Replikasi 2) dengan nilai sig,>0,05.

Dalam melakukan analisis varians satu jalur (OneWay Anova), syarat yang diperlukan adalah data normal dan homogen. Perhitungan uji normalitas dilakukan dengan bantuan aplikasi IBM SPSS 23. Hasil uji normalitas dapat dilihat pada Tabel 9. Uji normalitas menggunakan rumus Kolmogorov-Smimov dikarenakan apabila data yang akan diuji lebih dari 50, maka menggunakan rumus Kolmogorov-Smimov. Hasil Uji Normalitas menunjukkan bahwa nilai sig.> 0,05. Karena nilai sig.>0,05, maka dapat disimpulkan bahwa data yang digunakan berdistribusi normal.

Selanjutnya data diuji-tingkat homogenitasnya. Perhitungan uji-tingkat homogenitas dilakukan dengan bantuan aplikasi IBM SPSS 23. Hasil Uji homogenitas menunjukkan bahwa nilai sig.> 0,05. Karena nilai sig.>0,05, maka dapat disimpulkan bahwa data yang digunakan adalah homogen.

Setelah syarat data yang digunakan adalah normal dan homogen terpenuhi, selanjutnya dilakukan analisis varians satu jalur untuk mengetahui apakah terdapat perbedaan antara hasil peningkatan keterampilan berpikir kritis pada 3 kelas tersebut. Perhitungan analisis varians satu jalur dilakukan menggunakan bantuan aplikasi IBM SPSS 23. Hasil analisis varians satu jalur pada Tabel 6.

Tabel 6.

Hasil Uji Analisis Satu Varians (ANOVA)

\begin{tabular}{crrccc}
\hline & $\begin{array}{c}\text { Sum of } \\
\text { Squares }\end{array}$ & \multicolumn{1}{c}{ Df } & $\begin{array}{c}\text { Mean } \\
\text { Square }\end{array}$ & F & Sig. \\
Between & 22,487 & 2 & 11,244 &, 408 &, 666 \\
$\begin{array}{c}\text { Groups } \\
\text { Within }\end{array}$ & 2504,832 & 91 & 27,526 & & \\
Groups & & & & & \\
Total & 2527,319 & 93 & & & \\
\hline
\end{tabular}

Berdasarkan data pada Tabel 6, hasil analisis Varians Satu Jalur menunjukkan bahwa nilai sig.adalah 0,666. Karena nilai sig.>0,05, maka dapat disimpulkan bahwa tidak ada perbedaan antara hasil peningkatan keterampilan berpikir kritis pada 3 kelas yaitu kelas IVA, IVB, dan IVC.

Konsistensi peningkatan keterampilan berpikir kritis siswa juga dapat dilihat berdasarkan $N$-Gain tiap siswa di masing-masing kelas. Pada masing-masing kelas, $\mathrm{N}$-Gain tiap siswa mendapatkan rata-rata nilai 0,75 dengan berkategori tinggi. Hasil rata-rata $N$-Gain siswa tiap kelas dapat dilihat pada Gambar 4.

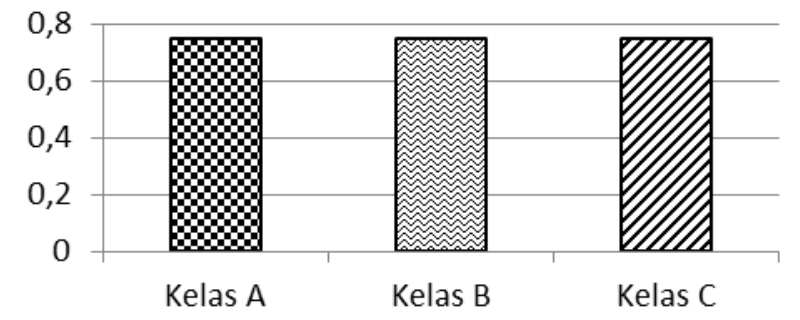

Gambar 4.

Hasil Rata-Rata N-Gain Siswa tiap Kelas

Pengisian angket untuk mendapat data respon siswa dilakukan oleh siswa. Angket diberikan kepada siswa kelas IVA, IVB, dan IVC. Pada saat pengisisan angket ditekankan bahwa angket yang diisi tidak berpengaruh terhadap penilaian pembelajaran agar siswa mengisi secara jujur. Respon siswa terhadap kegiatan pembelajaran secara ringkas dapat dilihat pada Tabel 7.

Tabel 7.

Hasil Analisis Respon Siswa

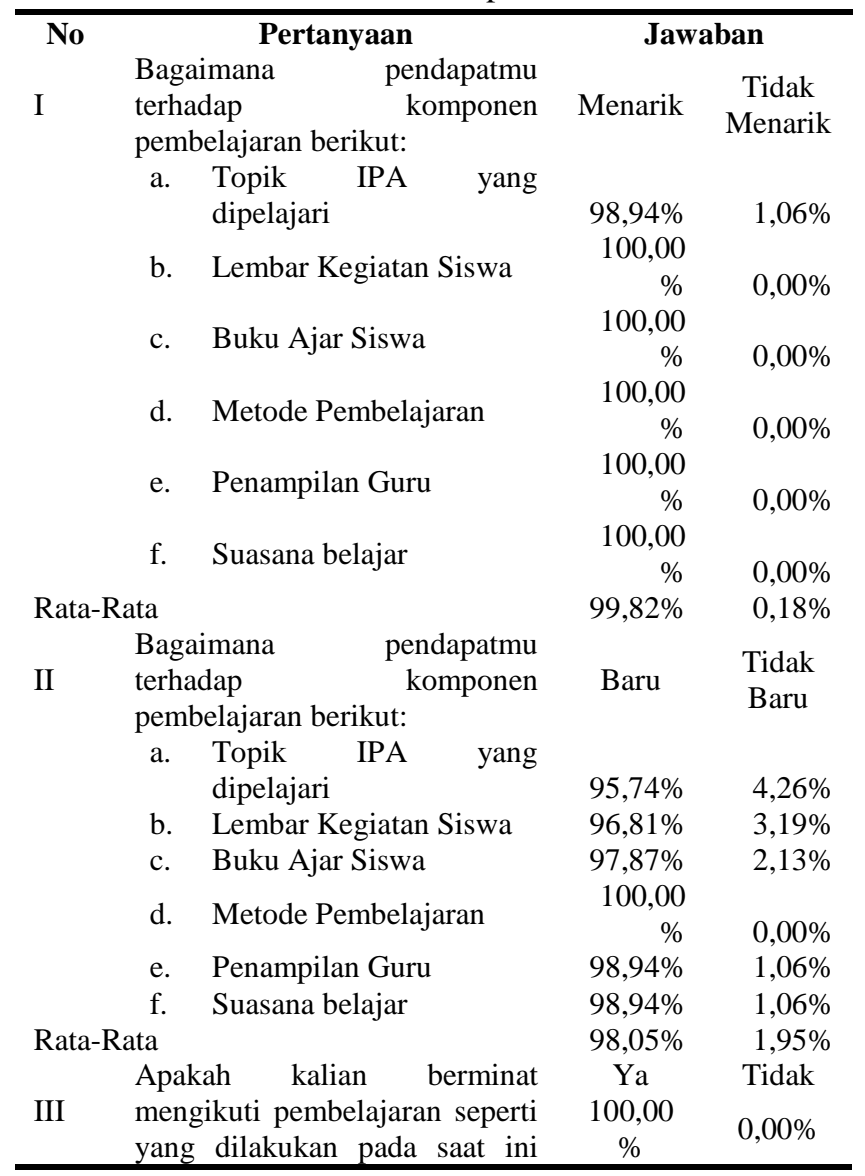




\begin{tabular}{|c|c|c|c|}
\hline \multirow{2}{*}{ No } & \multirow{2}{*}{$\begin{array}{l}\text { Pertanyaan } \\
\text { untuk topik IPA selanjutnya? } \\
\text { Bagaimana pendapat kalian } \\
\text { terhadap buku siswa mengenai: }\end{array}$} & \multicolumn{2}{|c|}{ Jawaban } \\
\hline & & $\mathrm{Ya}$ & Tidak \\
\hline \multirow[t]{2}{*}{ IV } & $\begin{array}{l}\text { Bahan Kajian mudah } \\
\text { dimengerti }\end{array}$ & $\begin{array}{r}100,00 \\
\%\end{array}$ & $0,00 \%$ \\
\hline & b. Isi Buku Menarik & $\begin{array}{r}100,00 \\
\%\end{array}$ & $0,00 \%$ \\
\hline \multicolumn{2}{|c|}{ Rata-Rata } & $\begin{array}{r}100,00 \\
\%\end{array}$ & $0,00 \%$ \\
\hline \multirow{6}{*}{$\mathrm{V}$} & $\begin{array}{l}\text { Bagaimana penilaian kalian } \\
\text { tentang keterampilan- } \\
\text { keterampilan berikut ini: }\end{array}$ & Senang & $\begin{array}{l}\text { Tidak } \\
\text { Senang }\end{array}$ \\
\hline & a. mengajukan pertanyaan & $94,68 \%$ & $5,32 \%$ \\
\hline & b. memrediksi & $96,81 \%$ & $3,19 \%$ \\
\hline & c. mengamati & $98,94 \%$ & $1,06 \%$ \\
\hline & d. mengukur & $\begin{array}{r}100,00 \\
\%\end{array}$ & $0,00 \%$ \\
\hline & e. mengklasifikasikan & $\begin{array}{r}100,00 \\
\%\end{array}$ & $0,00 \%$ \\
\hline \multicolumn{2}{|c|}{ Rata-Rata } & $98,09 \%$ & $1,91 \%$ \\
\hline \multirow{6}{*}{ VI } & $\begin{array}{l}\text { Bagaimana penilaian kalian } \\
\text { tentang keterampilan- } \\
\text { keterampilan berikut ini: }\end{array}$ & Baru & $\begin{array}{l}\text { Tidak } \\
\text { Baru }\end{array}$ \\
\hline & a. mengajukan pertanyaan & $97,87 \%$ & $2,13 \%$ \\
\hline & b. memrediksi & $96,81 \%$ & $3,19 \%$ \\
\hline & c. mengamati & $95,74 \%$ & $4,26 \%$ \\
\hline & d. mengukur & $95,74 \%$ & $4,26 \%$ \\
\hline & e. mengklasifikasikan & $94,68 \%$ & $5,32 \%$ \\
\hline \multicolumn{2}{|c|}{ Rata-Rata } & $96,17 \%$ & $3,83 \%$ \\
\hline \multirow[t]{2}{*}{ VII } & $\begin{array}{l}\text { Apakah kamu merasa mudah } \\
\text { untuk menjawab soal? }\end{array}$ & Mudah & $\begin{array}{l}\text { Tidak } \\
\text { Mudah } \\
8.05 \%\end{array}$ \\
\hline & ГA-RATA KESELURUHAN & $98,09 \%$ & $1,91 \%$ \\
\hline
\end{tabular}

Tabel 7. menunjukkan bahwa rata-rata respon siswa terhadap komponen pembelajaran adalah 99,82\% memilih menarik. Rata-Rata respon siswa terhadap komponen perangkat pembelajaran berbasis keterampilan proses adalah 98,05\% memilih baru. Minat siswa pada untuk mengikuti pembelajaran berbasis keterampilan proses selanjutnya adalah $100 \%$ memilih iya. Respon siswa terhadap kemenarikan BAS dan tingkat kesulitan BAS adalah $100 \%$ memilih iya. Respon siswa terhadap kesenangan siswa terhadap pembelajaran berbasis keterampilan proses adalah $98,09 \%$ senang. Respon siswa terhadap kebaruan pembelajaran berbasis keterampilan proses adalah sebesar 96,17\% memilih iya. Respon siswa terhadap kemudahan siswa menjawab butir soal setelah mengikuti pembelajaran berbasis keterampilan proses adalah sebesar 91,95\% memilih iya. Secara keseluruhan, respon siswa adalah sebesar 98,09\% siswa memilih baik pada semua komponen.

\section{HASIL DAN PEMBAHASAN}

Berdasarkan data yang telah dijabarkan pada dalam hasil penelitian, dapat dikatakan bahwa para validator sepakat jika perangkat pembelajaran IPA berbasis keterampilan proses adalah sangat relevan dengan kebutuhan atau harapan siswa kelas IV. Hal ini ditunjukkan oleh data hasil penilaian oleh para validator terhadap relevansi perangkat pembelajaran dengan kebutuhan dan harapan siswa. Penilaian para validator tersebut ternyata sejalan dengan respon siswa terhadap pembelajaran yang menerapkan keterampilan proses. Berdasarkan data angket respon siswa terhadap pembelajaran IPA diperoleh $100 \%$ siswa berminat dan senang dengan pembelajaran yang menerapkan keterampilan proses. Relevansi antara perangkat pembelajaran yang dikembangkan dengan kebutuhan siswa di abad 21 sesuai dengan pernyataan yang dimuat dalam Jurnal Institute of Museum and Library Services, (2009:28).

Kevalidan perangkat pembelajaran selain harus memenuhi validitas konten (isi), yang lebih penting lagi yaitu harus memenuhi validitas konstruk. Hal ini berarti bahwa penyusunan perangkat pembelajaran harus secara konsisten saling terkait dan secara logis memiliki format dan dasar teoritis yang jelas. Kevalidan perangkat pembelajaran berdampak pada hasil peningkatan keterampilan berpikir kritis. Menurut para validator, dengan menggunakan perangkat pembelajaran berbasis keterampilan proses maka dapat meningkatkan keterampilan berpikir kritis. Arends (2012) menyatakan bahwa penggunaan model, metode, atau pendekatan dalam pembelajaran tertentu dirancang untuk mencapai hasil belajar tertentu.

Keyakinan para validator bahwa perangkat pembelajaran berbasis keterampilan proses untuk meningkatkan keterampilan berpikir kritis didasarkan pada beberapa kajian teori belajar dan penelitian yang relevan. Salah satu teori melandasi adalah teori konstruktivisme Vygotsky. Siswa belajar dengan efektif apabila siswa tersebut membangun sendiri pengetahuannya (Suyono, 2014:105).

Kepraktisan perangkat pembelajaran berbasis keterampilan proses ini sebelumnya juga telah ditunjukkan pada hasil hasil observasi pembelajaran. Data pada kepraktisan pembelajaran bahwa kemampuan guru dalam melaksanakan pembelajaran memperoleh penilaian yang baik. Hal tersebut dimungkinkan disebabkan karena penggunaan perangkat pembelajaran berbasis keterampilan proses. Dengan demikian, meskipun dalam penelitian ini tidak bertujuan untuk mencari metode pembelajaran yang paling praktis, namun berdasarkan hasil tersebut diperoleh temuan bahwa pembelajaran berbasis keterampilan proses adalah baik untuk digunakan dalam kegiatan pembelajaran. Hal tersebut sesuai dengan pendapat Suryanti, dkk dalam 
Modul Suplemen Pengembangan IPA SD (2011) yang menyebutkan bahwa keterampilan proses dapat diterapkan untuk memperoleh hasil atau produk dalam pembelajaran secara efektif.

Pembelajaran IPA berbasis keterampilan berpikir kritis siswa meliputi kegiatan: memperhatikan penjelasan guru, membaca BAS dan mengerjakan LKS, berdiskusi/tanya jawab, menyiapkan alat dan bahan, melakukan percobaan, mempresentasikan hasil percobaan, merangkum materi pembelajaran, dan perilaku yang tidak relevan. Siswa lebih sering melakukan aktivitas memperhatikan guru. Hal tersebut dikarenakan siswa lebih sering memperhatikan penjelasan guru berupa instruksi pada saat melakukan percobaan. Sedangkan yang jarang dilakukan adalah kegiatan untuk mempresentasikan hasil percobaan. Hal tersebut dikarenakan presentasi hasil percobaan dilakukan setelah percobaan dan bergantian dengan kelompok lain.

Hasil positif aktivitas siswa tersebut sesuai dengan penelitian yang dilakukan oleh Balanay dan Roa (2013:25) bahwa pembelajaran berbasis keterampilan proses merupakan metode yang berfokus pada siswa, sehingga siswa akan aktif dalam pembelajaran, baik dalam memecahkan masalah, menjawab pertanyaan, mengajukan pertanyaan, berdiskusi, menjelaskan pendapat. Pembelajaran tersebut memungkinkan siswa untuk membangun sendiri pengetahuannya dan membuat pembelajaran lebih bermakna. Temuan ini juga sama dengan penelitian yang dilakukan oleh Chebii, dkk. (2012:1295) bahwa dengan keterampilan proses siswa dapat lebih aktif daripada guru. Siswa lebih banyak melakukan kegiatan sehingga siswa dapat menguasai pengetahuan dengan lebih baik.

Selama pembelajaran, tidak banyak ditemukan kendala pada saat kegiatan berlangsung. Namun ada beberapa hal yang perlu diperhatikan ketika pembelajaran. Saat pembelajaran siswa sering bermain-main dengan alatalat pembelajaran sehingga guru harus lebih tegas dalam mengingatkan siswa agar lebih fokus dalam pembelajaran. Siswa juga masih belum terbiasa dalam pembelajaran berbasis keterampilan proses, sehingga guru harus menjelaskan lebih mendalam tentang instruksi dalam lembar kegiatan siswa. Selain itu siswa kelas 4 juga masih belum terbiasa menggunakan stopwatch, sehingga butuh demonstrasi penggunaan stopwatch.

Berdasarkan data hasil penelitian yang dianalisis menggunakan Uji-t berpasangan, dapat diketahui bahwa terdapat perbedaan antara hasil pretes sebelum pembelajaran berbasis keterampilan proses dan postes setelah melakukan pembelajaran berbasis keterampilan proses. Berdasarkan hasil analisis menggunakan Uji-t berpasangan ternyata pembelajaran berbasis keterampilan proses dapat meningkatkan keterampilan berpikir kritis siswa secara signifikan. Data signifikansi peningkatan keterampilan berpikir kritis menggunakan keterampilan proses ternyata juga sesuai dengan hasil analisis N Gain. Perbedaan hasil sebelum dan sesudah pembelajaran berbasis keterampilan proses tersebut terlihat pada hasil $\mathrm{N}$ Gain per indikator keterampilan proses. Secara umum keterampilan berpikir kritis mengalami peningkatan tinggi (Sundayana, 2015:151).

Selain peningkatan pada setiap indikator, terdapat juga peningkatan keterampilan berpikir kritis setiap siswa, peningkatan keterampilan berpikir kritis siswa secara signifikan setelah dilakukan pembelajaran berbasis keterampilan proses. N-Gain setiap siswa kelas IVA menunjukkan bahwa 21 siswa menunjukkan peningkatan kategori tinggi, sedangkan 11 siswa menunjukkan peningkatan kategori sedang. Secara keseluruhan rata-rata $\mathrm{N}$-Gain setiap siswa adalah 0,75 dengan kategori tinggi. Pada kelas IVB sejumlah 18 siswa menunjukkan peningkatan kategori tinggi, sedangkan 12 siswa menunjukkan peningkatan kategori sedang. Secara keseluruhan rata-rata $N$-Gain setiap siswa adalah 0,75 dengan kategori tinggi. Pada kelas IVC sejumlah 17 siswa menunjukkan peningkatan kategori tinggi, sedangkan 15 siswa menunjukkan peningkatan kategori sedang. Pada tiga kelas ujicoba lapangan diperoleh $\mathrm{N}$-Gain tiap siswa mendapatkan rata-rata yang sama yaitu 0,75 dengan kategori tinggi. Hal tersebut menunjukkan bahwa peningkatan tiap siswa di tiga kelas sama besar dan memiliki pengaruh yang sama pada tiap sama.

Data nilai peningkatan keterampilan berpikir kritis siswa kelas IVA, IVB, dan IVC kemudian dikomparasikan dengan menggunakan rumus analisis varians satu jalur. Hasil analisis varians satu jalur menunjukkan bahwa nilai sig.adalah 0,666. Karena nilai sig.>0,05, maka dapat disimpulkan bahwa tidak ada perbedaan antara hasil peningkatan keterampilan berpikir kritis pada 3 kelas yaitu kelas IVA, IVB, dan IVC. Dengan demikian, ditinjau dari peningkatan keterampilan berpikir kritis, secara umum pembelajaran berbasis keterampilan proses ini dapat dikatakan efektif. Hal tersebut sesuai dengan penelitian yang dilakukan oleh Aktamis dan Ergin (2008) bahwa perangkat pembelajaran berbasis keterampilan proses dapat meningkatkan keterampilan berpikir kritis secara signifikan.

Peningkatan keterampilan berpikir kritis dengan menggunakan pembelajaran berbasis keterampilan proses sesuai dengan pendapat Wisudawati dan Sulistyowati 
(2014:26) yang mengatakan bahwa terdapat interaksiinteraksi antar komponen pembelajaran dalam bentuk proses pembelajaran untuk mencapai tujuan pembelajaran. Sehingga untuk mendapatkan tujuan pembelajaran yang sukses, maka pembelajaran harus ditekankan pada kegiatan berbasis keterampilan proses. Pendapat lain juga diungkapkan oleh Sugeng dan Irianto (2008:278) yang menyatakan bahwa IPA bukan hanya sekadar mendapatkan pengetahuan melalui sebuah hafalan, namun lebih menekankan pada proses penemuan pengetahuan itu sendiri. Temuan ini juga sama dengan penelitian yang dilakukan oleh Chebii, dkk. (2012:1295) bahwa terdapat peningkatan yang signifikan antara pembelajaran sebelum menerapkan keterampilan proses dengan pembelajaran setelah menerapkan keterampilan proses. Hasil pembelajaran meningkat dengan signifikan setelah menerapkan keterampilan proses dalam pembelajaran.

Keterampilan berpikir kritis merupakan keterampilan berpikir tingkat tinggi (Anderson \& Krathwol, 2001). Pembelajaran yang sesuai untuk mencapai hasil belajar dengan kategori berpikir tingkat tinggi adalah pembelajaran yang betul-betul memperhatikan pembelajaran bermakna. Menurut Slavin (2009), pembelajaran bermakna terjadi apabila suatu informasi baru masuk ke dalam pikiran yang terkait dengan pengetahuan yang dipelajari sebelumnya. Agar terjadi pembelajaran yang dapat meningkatkan pemahaman siswa diperlukan sebuah konteks yang tepat bagi siswa yaitu dengan menerapkan pembelajaran yang mengacu pada keterampilan proses Foulds dan Rowe (1996:16).

Hasil peningkatan keterampilan berpikir kritis tersebut berkaitan dengan aktivitas dan respon siswa. Siswa aktif dan sangat antusias ketika melakukan kegiatan pembelajaran berbasis keterampilan proses. Siswa sangat antusias dan bersemangat ketika diajak untuk melakukan kegiatan percobaan. Siswa bahkan ingin menerapkan pembelajaran yang sama di setiap mata pelajaran. Respon siswa pun terhadap pembelajaran adalah positif. Menurut salah satu siswa dalam pembelajaran, dalam pembelajaran sebelumnya tidak ada pembelajaran seperti yang diajarkan pada saat menerapkan pembelajaran berbasis keterampilan proses yang menekankan pada siswa langsung terkait dengan kegiatan pembelajaran. Sehingga, siswa lebih mudah memahami materi yang diajarkan. Hal tersebut dapat dijadikan petunjuk bahwa terdapat hubungan antara aktivitas dan respon siswa terhadap peningkatan keterampilan berpikir kritis siswa.

Pengisian angket untuk mendapat data respon siswa dilakukan oleh siswa. Pada saat pengisisan angket ditekankan bahwa angket yang diisi tidak berpengaruh terhadap penilaian pembelajaran agar siswa mengisi secara jujur. Hasil angket respon siswa menujukkan rata-rata respon siswa terhadap komponen pembelajaran adalah 99,82\% memilih menarik. Rata-Rata respon siswa terhadap komponen perangkat pembelajaran berbasis keterampilan proses adalah 98,05\% memilih baru. Minat siswa pada untuk mengikuti pembelajaran berbasis keterampilan proses selanjutnya adalah $100 \%$ memilih iya. Respon siswa terhadap kemenarikan BAS dan tingkat kesulitan BAS adalah 100\% memilih iya. Respon siswa terhadap kesenangan siswa terhadap pembelajaran berbasis keterampilan proses adalah 98,09\% senang. Respon siswa terhadap kebaruan pembelajaran berbasis keterampilan proses adalah sebesar 96,17\% memilih iya. Respon siswa terhadap kemudahan siswa menjawab butir soal setelah mengikuti pembelajaran berbasis keterampilan proses adalah sebesar 91,95\% memilih iya. Secara keseluruhan, respon siswa adalah sebesar 98,09\% siswa memilih baik pada semua komponen.

\section{PENUTUP}

\section{Simpulan dan Saran}

Berdasarkan hasil penelitian dan temuan penelitian dirumuskan simpulan yaitu perangkat pembelajaran IPA berbasis keterampilan proses telah memnuhi kriteria kelayakan yaitu, valid, praktis, dan efektif. Secara lebih khusus dijabarkan sebagai berikut. (1) Perangkat pembelajaran IPA berbasis keterampilan proses telah memenuhi syarat kevalidan. Syarat tersebut mencakup antara lain. (a) Perangkat pembelajaran IPA berbasis keterampilan proses telah memenuhi syarat kevalidan ditinjau dari validitas konten dan konstruk. (b) Perangkat pembelajaran IPA berbasis keterampilan proses telah memenuhi syarat kevalidan ditinjau dari keterbacaan. (c) Perangkat pembelajaran IPA berbasis keterampilan proses telah memenuhi syarat kevalidan ditinjau dari tingkat kesulitan. (2) Perangkat pembelajaran IPA berbasis keterampilan proses telah memenuhi syarat kepraktisan. Syarat tersebut mencakup antara lain. (a) Perangkat pembelajaran IPA berbasis keterampilan proses telah memenuhi syarat kepraktisan ditinjau dari keterlaksanaan pembelajaran. (b) Perangkat pembelajaran IPA berbasis keterampilan proses telah memenuhi syarat kepraktisan ditinjau dari kendala-kendala pembelajaran yang dapat teratasi dengan baik. (3) Perangkat pembelajaran IPA berbasis keterampilan proses telah memenuhi syarat keefektifan. Syarat tersebut mencakup antara lain. (a) Perangkat pembelajaran IPA berbasis keterampilan proses telah memenuhi syarat keefektifan ditinjau dari peningkatan keterampilan berpikir kritis siswa. (b) 
Perangkat pembelajaran IPA berbasis keterampilan proses telah memenuhi syarat kepraktisan ditinjau dari aktivitas siswa. (c) Perangkat pembelajaran IPA berbasis keterampilan proses telah memenuhi syarat kepraktisan ditinjau dari respon siswa.

Berdasarkan hasil penelitian dan kesimpulan dirumuskan saran sebagai berikut. (1) Jumlah validator perangkat pembelajaran sebaiknya ditambah minimal tiga validator. Hal tersebut agar mendapatkan penilaian yang lebih nyata dan teliti. (2) Jumlah siswa yang digunakan untuk uji instrumen keterbacaan BAS dan tingkat kesulitan BAS sebaiknya ditambah. (3) Sebelum pelaksanaan pembelajaran menggunakan perangkat pembelajaran berbasis keterampilan proses, sebaiknya guru mendapat pelatihan terlebih dahulu agar pembelajaran yang telah disusun sebelumnya bisa terlaksana dengan lebih baik. (4) Dalam penelitian selanjutnya perlu diuji juga kelayakan perangkat pembelajaran dari segi efisiensi. Hal tersebut berguna agar perangkat pembelajaran yang dikembangkan memiliki tingkat efisiensi yang baik dan bisa dijangkau untuk guru manapun.

\section{DAFTAR PUSTAKA}

Aktamis, H. dan Ergin, O. (2008). The Effect of Scientific Process Skills Education on Student's Scientific creativity, Science Atitude and Academic Achievements. Asia-Pasific Forum on Science Learning and Teaching Journal, Volume 9, Issue I. 2008.

Anderson dan Krathwohl. (2001). A Taxonomy for Learning, Teaching, and Assesing: A Revision of Bloom's Taxonomy of Educational Objectives. Diterjemahkan oleh Agung Prihantoro. Yogyakarta: Pustaka Pelajar.

Arends, R. I. (2012). Learning to Teach. Ninth Edition. New York: McGraw-Hill.

Arifin. 2009. Evaluasi Pembelajaran. Bandung: PT. Remaja Rosdakarya.

Balanay, C.A.S. dan Roa, E.C. (2013). Assessment on Students' Science Process Skills: A StudentCentred Approach. International Journal of Biology Education. Vol. 3, Issue 1.

Chebii, R, Wachanga, S. dan Kiboss, J. (2012). Effects of Science Process Skills Mastery Learning Approach on Students' Acquisition of Selected Chemistry Practical Skills in School. Scientific Research Journal. Vol.3, No.8, 1291-1296. Diunduh dari http://www.SciRP.org/journal/ce/

Deanna, D. dan Kuhn, D. (2003). Metacognition and Critical Thinking, Educational Resources Information Center. ERIC Number: ED477930
Diunduh dari http://www.files.eric.ed.gov/fulltext/ED477930. pdf

Facione, P. A. (1990). Critical Thinking: A Statement of Expert Consensus for Purposes of Educational Assessment and Intruction. California: California Academic. Press.

Foulds, W. dan Rowe, J. (1996). The Enhancement of Science Process Skills in Primary Teacher Education Students. Australian Journal of Teacher Education. Volume 21-Issue 1

Institute of Museum and Library Services (2009). Museums, Libraries, and 21st Century Skills (IMLS-2009NAI-01). Washington, D.C.

Mulyasa. (2010). Kurikulum Tingkat Satuan Pendidikan. Bandung: Remaja Rosdakarya.

OECD/Asian Development Bank. (2015). Education in Indonesia: Rising to the Challenge. OECD Publishing: Paris.

Ratumanan, T dan Laurens, T. (2006). Evaluasi Belajar yang Relevan dengan KBK. Surabaya: Unesa University Press

Rauf, R., Rasul, M.S., Mansor, A. N., Othman, Z. dan Lyndon. (2013). Inculcation of Science Process Skills in a Science Classroom. Asian Social Science Journal, Vol. 9. No. 8. 2013. Publisheb by Canadian Center of Science and Education

Samatowa. 2011. Pembelajaran IPA di Sekolah Dasar. Jakarta: Indeks

Slavin, R. E. (2009). Educational Psychology Theory and Practice. Ninth Edition. New Jersey: Pearson Education

Sugiyono. (2012). Metode Penelitian Kuantitatif, Kualitatif, dan R\&D. Bandung: Alfabeta

Sugeng dan Irianto. 2008. Asyiknya Belajar Fisika SMP. Jakarta: Departemen Pendidikan Nasional

Sitepu, B. P. (2010). Keterbacaan. Dapat diakses pada (https://bintangsitepu.wordpress.com/2010/09/1 1/keterbacaan/)

Sundayana, R. (2015). Stastitika Penelitian Pendidikan. Bandung: Alfabeta.

Suryanti. Widodo, W. Mintohari. (2011). Modul Suplemen Pengembangan IPA SD. Surabaya:Unesa Press

Suyono dan Hariyanto. (2014). Belajar dan Pembelajaran, Teori dan Konsep Dasar. Bandung: Remaja Rosdakarya.

Thiagarajan, S. Semmel, M.I. dan Semmel, S.D. (1974). Instructional Development for Training Teachers of Exceptional Children: A Sourcebook. Diunduh dari 
http://www.files.eric.ed.gov./fulltext/ed090725.p df

Trianto. (2007). Model Pembelajaran Terpadu dalam Teori dan Praktik. Jakarta: Prestasi Pustaka.

Widuwati, Asih W. dan Sulistyowati, E. (2014). Metodologi Pembelajaran IPA. Jakarta: PT Bumi Aksara. 